\title{
SAFETY MANAGEMENT SYSTEM OF POLAND'S RAILWAY TRANSPORT
}

\section{SYSTEM ZARZĄDZANIA BEZPIECZEŃSTWEM TRANSPORTU KOLEJOWEGO POLSKI}

\author{
Marek Sitarz $^{1}$, Katarzyna Chruzik ${ }^{2}$ \\ $(1,2)$ Silesian University of Technology, Faculty of Transport, \\ Department of Railway Mechanic \\ Politechnika Śląska, Wydział Transportu, Katedra Transportu Szynowego \\ e-mails: (1) marek.sitarz@polsl.pl, (2) katarzyna.chruzik@polsl.pl
}

\begin{abstract}
Since the beginning of railway transport existence, there have been the internal rules concerning its safety. There were and are still now placed under a full supervision the means of transport (railway rolling stock as well as the infrastructure) and the periodical trainings of operators. The Security plays very important part in railway transport both in aspect of goods for the railway system (from the stage of design, through the production, qualifications as well as the exploitations as far as to the repair and modernizations), as well as in the scope of the Safety Management Systems of both the railway carriers and the infrastructure managers.
\end{abstract}

Key Words: transport, safety, Safety Management System

Streszczenie. O samego początku swojego istnienia w transporcie kolejowym istniały wewnętrzne przepisy dotyczące jego bezpieczeństwa. Pełnym nadzorem objęte są w nim środki transportu (tabor i infrastruktura) jak i okresowe szkolenia operatorów. Bezpieczeństwo odgrywa w transporcie kolejowym bardzo dużą role, tak w aspekcie wyrobów dla kolejnictwa (od etapu projektowania, poprzez produkcje, kwalifikacje i eksploatacje aż po naprawę i modernizacje), jak i w zakresie systemów zarządzania bezpieczeństwa przewoźników kolejowych i zarządców infrastruktury.

Slowa kluczowe: transport, bezpieczeństwo, System Zarządzania Bezpieczeństwem 


\section{SAFETY MANAGEMENT SYSTEM OF POLAND'S RAILWAY TRANSPORT}

\section{Introduction}

The safety of railway transport is the major criterion of the evaluation of the transport railway system functioning, decides both about its efficiency as well as about the widely comprehended quality of the transport service being in offer [1].

The theory of systems' safety finds a particular application in transport systems. The electronic devices and elements used in these systems in the wide range and particularly the microprocessor's systems, evoke the need of new approach to the operational reliability of the composed transport systems. The serious problem constitute the difficult and complex conditions of the transport systems' exploitation being exposed in practice to all types of disturbances; more satisfying according the safety theory requires the "system-operator" problem.

The notion quality systems was used in order to define the systems, where the formation of the dangerous situations has been eliminated. The special methods of design, setting in motion, installations as well as the servicing or dangerous situations analysis with the help of the diagnosis method of causes and effects of errors formation in system, they assure the achievement of the same purpose such as the guarantee, that the known categories of errors will not cause the critical break-down [1].

Taking into consideration the presented methodology of both forming and reaction towards the railway transport safety, it is worth watching legal and normative conditionings, which are currently being in force in the European Union. The Directive 2004/49/EC of the European Parliament and the Council of the European Union, the Railway Transport Act of Parliament from the 28 th of March 2003 (unified text), (amended on the $22^{\text {nd }}$ of July 2006) as well as the Decrees of the Minister of Transport from the $19^{\text {th }}$ of March 2007r. regarding the Safety Management System in the railway transport, they oblige both the subjects providing the railway transport services as well as the managers of the railway infrastructure to obtain the Certificate of Safety, guaranteeing the appropriate level of the safety of railway transports assurance until the $30^{\text {th }}$ of June 2010 . The Certificate of 
Safety is the document, which confirms the establishing by the railway carrier the Safety Managament System as well as his aptitude to fulfil the safety requirements, which have been included in the Technical Interoperability Specifications as well as in others regulations of the national and common law. The obtainment of this document authorizes to have an access to the railway infrastructure.

Certificate consists of two parts:

- The first one accepting the Safety Management Systems;

- The second one, the network part accepting the internal regulations in order to fulfil the necessary requirements for safe carrying out the national transports on a given railway system [1].

\section{The diagnosis of the state of safety of the railway traffic in Poland}

Total diagnosis of the state of safety of the railway transport is annually elaborated by the Railway Transport Office. The presented below data are being taken from the aforementioned Report for 2006 [4].

\subsection{Quantitative list of the accidents in the period between the 2005 and 2006}

The number of the railway accidents in 2006 in comparison with the previous year is presented in the following way:

- The number of the train accidents has augmented from 365 to 433 i.e. it is increased by $18,6 \%$,

- The number of the serious accidents has diminished from 93 to 84, i.e. it is decreased by $10 \%$,

- From the overall number train accidents:

427 accidents took place in the companies of the PKP Group,

6 accidents on the premises of residual railway enterprises;

- The measurer of accidents, i.e. number of accidents occuring per 1 million of train kilometres, has increased from 1,58 to 1,64 , i.e. by $3,8 \%$,

- Number of the switching accidents has elevated from 73 to 87, i.e. by $19 \%$, including these, which happened on premises of the PKP Group Companies -84 accidents, and 4 accidents in the residual enterprises. 


\subsection{The overall characteristics of accidents}

The fundamental causes of the railway accidents are the following:

The injuries at work - The diminution of the accidents provoked by fault of the railway workers from 20 to 13 was recorded, which should be estimated positively, while it indicates the improvement of the training's quality as well as the good work of direct supervision service,

Technical accidents - there occurred a very significant growth of such type of accidents, namely from 46 to 83 ;

Such type of accidents consist of:

- Technical defects of surface - increase from 28 to 38 accidents

- Technical defects of wagons - increase from 13 to 19 ,

- Technical defects of locomotives - increase from 5 to 26.

Accidents at the railway crossings - the increase of accidents occurred from 253 to 279 , i.e. by $10,3 \%$ and these accidents constitute $70 \%$ of the overall train accidents. Despite the increase of these accidents' type, the number of casualties has decreased, it was showed in the following data:

- Death people number has decreased from 42 to 32,

- $\quad$ The wounded people number decreased from 115 to 91.

\subsection{The technical state of the railway infrastructure as well as the rail- vehicles}

Technical state of track structure undergoes the progressing degradation because of insufficient quantity of maintenance and repair works. It causes the augmentation of safety hazard of railway traffic. The annual requirements of major repairs performance resulting from the repair cycles amount to about $1390 \mathrm{~km}$, in $2006380 \mathrm{~km}$ was performed, i.e. $27 \%$, and the annual requirements of railway junctions replacements amount to about 2490 units of railway junctions, in 2006 there were replaced 242 railway junctions, i.e. $9,7 \%$. It should be emphasized, that according to the requirements at the end of the 2006, the arrears in performance of the required major repairs were equal to: $10300 \mathrm{~km}$ of tracks and 17100 units of railway junctions. The image of the railway infrastructure degradation reflects the quantity of speed limits, that were imposed. At the end of the 2006 there were obligatory 4855 speed limits, and at the end of 2005 there were 4239 ones, which signifies the growth at the level of 616 units, i.e. they increased by $14,5 \%$.

In order to improve the state of the basic infrastructure i.e. (tracks and railway junctions) the following activities are required: 
- Radical rise of the scopes of the major repairs and the current repairs of tracks as well as railway junctions,

- Acceleration rate of railway rails replacement, which underwent the heat treatment,

- The main manager of the railway infrastructure of the PKP PLK Joint Stock Company, shall elaborate and present to the Government Department Administration the schedule of liquidation of the speed limits.

The number of the out-dated railway traffic control-systems both (machinery and the mechanical and electrical ones) decreases annually. However, the implementation of the modern control- systems is too slow .

In 2006 the double growth quantity in the trains delay caused by the railway traffic control-systems defects were recorded. It arises from the prolongation of defects duration and general reason responsible for it, are the significant shortages in the employment of the qualified workers dealing with the direct maintenance as well as the complete exploitation of the currently existing devices.

The double growth plus of the quantities of detected defects in the railway rolling stock gives evidence about the bad technical state of the rail-vehicles It shows the necessity of work discipline of the railway rolling stock auditors, as well as undertaking the activities aiming at the restoration of the fleet of railway rolling stock.

The persistence of large railway traffic safety hazard is caused by both the stealing and devastation of elements of the railway traffic control-systems, and the quantity of train delays based on this grounds has augmented at almost $60 \%$ in 2006 in comparison with the previous year. The quantity of delays depends on the possibility of repair of devastated and stolen device, which is influenced by the shortages in the personnel employment dealing with the maintenance service. The burglary and devastation related costs incurred by the managers of infrastructure are still very high (about $8,2 \mathrm{mln}$ zł in 2006). These costs have exceeded almost four times the renovation of railway traffic control systems related inputs.

In 2006 was recorded the increase of accidents quantity from 5 to 26 because of the technical defects of locomotives in relation to the previous year, as well as the accidents growth form 13 to 19 caused by the technical defects of wagons.

Anxious is the growth level from 3 to 7 of the accidents number related to the unsatisfactory state of the railway rolling stock of the railway carriers apart from the PKP Group. The significantly worked out traction vehicles constitute the serious problem, the evidence of it is the mean time of 
exploitation, which in case of the PKP CARGO Joint Stock Company exceeds 29 year period of time as far as diesel-electric locomotives are concerned and for the wagons this time exceeded 24 years. The additional problem constitutes the diminution of repairs number carried out in 2006 and periodical surveys. In the passenger railway rolling stock the mean time of exploitation amounts to:

28,9 years in the PKP company - The Regional Transport Services,

21,5 years in the PKP Intercity Company.

Moreover, this railway rolling stock possesses out-dated technical solutions. In 2006 was stated double plus growth of the quantity of defects, which were detected in the exploited railway rolling stock on railway lines.

The improvement of the safety of rail-vehicles traffic requires the following activities:

- The decrease of the mean age of the rail-vehicles being in exploitation through eliminating from the exploitation the most outworn (exploited) ones and the purchase of the new ones at the same time,

- Accelerations of the modernization of the exploited rail-vehicles and particularly the locomotives type of ET22 and EP09,

- The quantity improvement of the carried out periodical surveys,

- The enlargement of the supervision over the quantity of the carried out repairs thanks to the urgent setting up the independent of the carriers group of the commissars- recipients of services.

In order to improve the railway traffic connected with the implementing into the exploitation the imported rail - vehicles, the President of the Railway Transport Office created the group responsible for the verification of the conditions of admission to the Polish railway system of such rail-vehicles it concerns particularly the cooperation conditions track - vehicle.

\section{The diagnosis of the safety system of the railway traffic in Poland}

The two organizational units in Poland responsible for both the monitoring as well as the safety estimation are The Railway Transport Office (UTK) and The Governmental Rail Accident Investigation Branch (RAIB).

The tasks of the President of the Railway Transport Office UTK in the scope of the traffic safety in the railway transport result from the Railway Transport Act of Parliament from the $28^{\text {th }}$ of March 2003 and they regard in particular the:

- the technical supervision over the exploitation of the railway lines as well as the safety of the railway traffic; 
- the supervision over the safe railway transport of the hazardous goods

The Organization of the Safety Assurance System of Railway Transport is based on the task division as well as it transfers the responsibility for its condition to the managers of the railway infrastructure, the railway carriers as well as to the users of railway sidings

In accordance with the article 5 of the Railway Transport Act of Parliament the manager of infrastructure is obliged to maintain the railway infrastructure in the state, which assures the safe railway traffic running.

On the other hand, according to the 17 article of this Act of Parliament the railway managers, railway carriers as well as the users of railway sidings are obliged to fulfil the technical specifications as well as the organizational ones, which assure -

- the safe running of railway traffic,

- the safe exploitation of rail-vehicles

The next organization set up in 2007 is the Governmental Rail Accident Investigation Branch (RAIB), it deals with the conducts the researches of serious accidents, accidents as well as the incidents and it acts in cooperation with the competent Minister responsible for the transport affairs. Governmental Rail Accident Investigation Branch (RAIB) fulfils its tasks on behalf of the competent Minister dealing with the Transport Affairs. This Committee conducts the legal proceedings after each occurrence of the serious accident on the railway system excluding the incidents of overrunning of the rail-vehicle into the people during the level crossing. The RAIB draws up a report from these legal proceedings, containing the recommendations in the scope of the railway safety improvement as well as the prevention of the serious accidents, accidents or incidents, by making the resolution in this domain.

The recommendations in range of the safety improvement as well as the prevention of the serious accidents occurrence or accidents or incidents cannot include statement of both blame and responsibility.

Governmental Rail Accident Investigation Branch (RAIB) draws up an annual report from its works, carried out in the previous year till the $30^{\text {th }}$ of March. This report contains the issued recommendations in the safety domain as well as the activities undertaken in compliance with these recommendations and subsequently it is transferred by the Governmental Rail Accident Investigation Branch RAIB to the Agency. The annual report is announced not later, than to the $30^{\text {th }}$ of July. The RAIB pronounces the reports through the announcement in the Official Journal of the Competent Minister Responsible for the Transport Affairs. 
The President of Railway Transport Office UTK supervises, in the scope of his qualifications, the realization of the recommendations regarding dealing with the post-accident incidents, which are delivered by the RAIB.

The President of the Railway Transport Office UTK presents each year to the RAIB, the information concerning the realization of the transferred by the Governmental Rail Accident Investigation Branch recommendations, as well as the activities aiming at the execution of this recommendations, the implementary acts from the Official Journal.

\section{The programming of the security improvement principles}

According to the aforementioned data, the serious railway accidents take place relatively rarely, however they have got the catastrophic effects and they provoke the anxiety in public opinion as far as the railway safety is concerned. Therefore, it is necessary to research all the events in relation to the possibility of avoidance of the similar accidents and the investigation results should be published.

The potentially accident related incidents as well as events, (which could cause the accidents), should constitute the significant events, preceding accidents and should be subject to the research carrying out in the range of safety. Reports from the investigations as well as all the conclusions and recommendations constitute the important information in relation to further railway safety development and they should be accessible publicly. The recommendations should be made by their addressee and the reports from the activities should be transferred to the investigation body, which carries out the researches. The detailed pieces of information connected with the reports' content regarding the investigation in case of the accidents as well as the incidents are comprised in the enclosure $\mathrm{V}$ of the Directive (2004/49/EC) of the European Parliament and the European Council from the $29^{\text {th }}$ of April 2004, in the railway safety affair [2].

The European Transport Safety Council (ETSC) has published in 2004 report titled "The safety indicators in transport ".

It postulated in it the solutions concerning the objectives connected with improvement of the safety in all types of transport, both at the European as well as the national level. Those safety related solutions consisted of the following:

- creation of the list of safety indicators as the method of trends determination in the level of safety as well as the efficiency evaluation of the number of casualties limitation Programmes, 
- establishing of the Working Group, which will elaborate the list of essential safety indicators,

- carrying out of the feasibility study of data collection,

- the requirement for the European Union member countries, to collect data regarding the safety indicators in the " uniform and regular way" and that current monitoring of the safety become the " integral element of their strategy related to the national security assurance ";

- transfer to the European Union member countries the directives concerning both the methodology of monitoring as well as the data collection;

- the publication of reports showing the annual trends in the European Statistical Yearbooks with the help of Internet as well as of the Road Safety Information System RSIS of the European Commission;

- requirement from the European Union member countries to deliver in a regular way the indicators data as well as to implement Programmes of the Indicators Improvement;

- introduction to the list of problems of the EU Seventh Research and Development Framework Programme (FP7), further researches regarding both the methods of carrying out as well as the estimation of the Integrated Programmes of Safety Management and the establishment of the dependences between the indicators and the number of the accidents;

- instructions of the best methods of taking advantage of the safety indicators in transport [3].

On this basis, the division of the safety indicators was performed and it was presented in the following way:

\section{The safety indices relating to the accidents}

1. The whole and relative (in calculation to train kilometers), number of the accidents with the division into the following types of accidents:

- train collisions, together with the collisions including the objects inside the gauge;

- trains derailments;

- accidents on the railway crossings, together with the accidents of pedestrians on the railway crossings;

- accidents of people, which were caused by the railway rolling stock in motion excluding the suicidal attempts;

- suicidal attempts;

- fires of the railway rolling stock;

- others. 
2. The whole and relative number of people seriously wounded and killed in calculation to the train kilmetres, according to the type of accident, divided into the below mentioned categories:

- passengers (also in calculation to the passenger-kilometres);

- workers, together with the workers of the subcontractors;

- users of the railway crossings;

- intruders in the railway compartments;

- others.

\section{The safety indices regarding the avoided incidents and accidents}

1. The whole and relative number of the railway rails cracks, tracks clamps, railroad signalling defects, (in calculation to train kilometres);

2. The whole and relative number of the transferred alarm signals (in calculation to train kilometers);

3 . The whole and relative number of the cracked both wheels as well as axles in the used railway rolling stock (in calculation to train kilometers).

\section{Safety indices concerning the results of accident}

1. The total and relative cost in the EURO currency of all the accidents (in calculation to train kilometers); together with, if it is possible with calculation and taking into consideration the following costs elements:

- in cases of accidents casualties;

- compensations for loss and devastation of passengers' property, personnel or the third parties, taking into account the environment damages;

- replacements or the repairs of the devastated railway rolling stock as well as the railway installations;

- delays, disturbances and the railway detours, including the additional costs of labour and costs connected with loss of the future incomes.

2. The total and relative number of working hours (in calculation to the worked hours) of both the personnel and the subcontractors, which has been lost in result of the accidents.

\section{The indicators concerning the technical safety of the infrastructure and its application}

1. Percentage of the tracks functioning with the help of the Automatic Train Protection Systems - ATP as well as the percentage of the train kilometers executed on the tracks, equipped with the Automatic Train Protection Systems - ATP. 
2. Number of the railway crossings - the total number and per kilometer. The percentage of the railway crossings with the automatic barriers or the manual ones.

\section{$\mathrm{V}$. The indicators regarding safety management}

Internal audits carried out by the infrastructure managers as well as by the railway enterprises in accordance with the documentation of the Safety Management Systems. The total number of the audits performed and the number considered as the percentage of the required and/or planned audits [5]. Sharing the idea of the new legal regulations, the railway carriers and at the same time the people, who make accessible the railway infrastructure they assume responsibility for the railway traffic safety.

However, the correct Safety Management System requires the system approach. It is necessary to emphasize that, currently last the intensive scientific works of the European Commissions in the scope of range of problems connected with the application of the safety indicators.

\section{Summary}

The principal emphasis is placed on the errors identification, the analysis of their causes as well as on the limitation of their effects, as far as the safe systems work verification is concerned in the hazardous fields, menaced by the catastrophic effects of errors. There should be engaged two parties during the process of safety system defining, namely the systems designerproducer - supplier on the one hand, and on the other hand the future user , who should have the influence on defining the hazardous situations, the reaction of the system to the errors as well as the damages (especially in the hazard related situations), and also determination of the conditions of implementation as well as the system's maintenance. The currently developed theory of systems safety, especially in France, Great Britain, the United States of America as well as in Poland, makes possible the effective solution of the discrepancies between the compilation of the transport systems structure and the necessity of their safe and reliable operation. The solution of this aforementioned discrepancy will decide in the following years about the safety of the railway traffic. The intensive activation in the development of the systems' safety theory, will enable the fast and direct putting the obtained solutions into operating practice of the PKP Joint Stock Company. 
The presented material in this article, constitutes the part of the project The Integrated Safety Management System ZEUS - PBZ-MEiN-7/2/2006

\section{List of the literature}

1. Dyduch J: Zielony semafor. Transport i Komunikacja 2007 nr 1 s.80-81.

2. Dyrektywa 2004/49/WE PARLAMENTU EUROPEJSKIEGO I RADY z dnia 29 kwietnia $2004 \mathrm{r}$.

3. Raport "Wskaźniki bezpieczeństwa w transporcie", Europejska Rada Bezpieczeństwa w Transporcie (ETSC) z 2004 r.

4. Raport w sprawie bezpieczeństwa transportu kolejowego Polski w roku 2006

5. Załącznik I do Dyrektywy 2004/49/WE PARLAMENTU EUROPEJSKIEGO I RADY z dnia 29 kwietnia 2004 r. 


\section{SYSTEM ZARZĄDZANIA BEZPIECZEŃSTWEM TRANSPORTU KOLEJOWEGO POLSKI}

\section{Wstęp}

Bezpieczeństwo transportu kolejowego jest podstawowym kryterium oceny funkcjonowania transportowego systemu kolejowego, decyduje o jego sprawności jak również o szeroko rozumianej jakości oferowanej usługi przewozowej [1].

Teoria bezpieczeństwa systemów znajduje szczególne zastosowania w systemach transportowych. Stosowane w tych systemach w szerokim zakresie urządzenia i elementy elektroniczne, a zwłaszcza systemy mikroprocesorowe, wywołują potrzebę nowego spojrzenia na niezawodność funkcjonalną złożonych systemów transportowych. Poważnym problemem są trudne i złożone warunki eksploatacji systemów transportowych, narażonych na oddziaływanie praktycznie wszystkich rodzajów zakłóceń; pełniejszego rozwiązania z punktu widzenia teorii bezpieczeństwa wymaga problem ,system-operator".

Przez systemy bezpieczne (ang. quality systems) określane są systemy, w których wyeliminowano powstawanie sytuacji niebezpiecznych. Specjalne metody projektowania, uruchamiania, instalacji i obsługi bądź analiza sytuacji niebezpiecznych metodą diagnostyki skutków i przyczyn powstawania błędów w systemie, zapewniają osiagnięcie tego samego celu, jakim jest gwarancja, że znane kategorie błędów nie spowodują krytycznej awarii [1].

Uwzględniając przedstawioną metodykę kształtowania i oddziaływania na bezpieczeństwo transportu kolejowego warto prześledzić uwarunkowania prawno-normatywne obowiązujące obecnie w Unii Europejskiej.

Dyrektywa 2004/49/WE Parlamentu Europejskiego i Rady Unii Europejskiej, Ustawa o transporcie kolejowym z 28 marca 2003(tekst ujednolicony), Ustawa $\mathrm{z}$ dnia 22.07.2006 o zmianie ustawy o transporcie kolejowym oraz Rozporządzenia Ministra Transportu z dnia 19 marca 2007r. W sprawie systemu zarządzania bezpieczeństwem w transporcie kolejowym nakładają na podmioty świadczące przewozy kolejowe oraz na zarządców infrastruktury kolejowej obowiązek uzyskania do dnia 30 czerwca 2010 r. certyfikatu bezpieczeństwa gwarantującego zapewnienie odpowiedniego poziomu bezpieczeństwa przewozów kolejowych. 
Certyfikat bezpieczeństwa jest dokumentem potwierdzającym ustanowienie przez przewoźnika kolejowego Systemu Zarządzania Bezpieczeństwem oraz zdolności spełnienia przez niego wymagań bezpieczeństwa zawartych w7 Technicznych Specyfikacjach Interoperacyjnych i innych przepisach prawa wspólnotowego i krajowego. Uzyskanie tego dokumentu uprawnia do uzyskania dostępu do infrastruktury kolejowej.

Certyfikat składa się z dwóch części:

- pierwsza akceptująca systemy zarządzania bezpieczeństwem

- druga, część sieciowa akceptująca wewnętrzne regulacje w celu spełnienia wymagań niezbędnych do bezpiecznego wykonywania przewozów krajowych na danej sieci kolejowej [1].

\section{Diagnoza stanu bezpieczeństwa ruchu kolejowego w Polsce [4]}

Pełna diagnoza stanu bezpieczeństwa transportu kolejowego jest corocznie opracowywana przez Urząd Transportu Kolejowego. Poniższe dane są zaczerpnięte ze wspomnianego wyżej Raportu za rok 2006.

\subsection{Ilościowe zestawienie wypadków w latach 2005 i 2006}

Liczba wypadków kolejowych w 2006 roku w porównaniu do roku poprzedniego przedstawia się następująco:

- liczba wypadków pociągowych wzrosła z 365 do 433, tj. o 18,6\%,

- liczba poważnych wypadków zmniejszyla się z 93 do 84, tj. o 10\%,

- z ogólnej liczby wypadków z pociagami:

427 wypadków miało miejsce w Spółkach Grupy PKP,

6 wypadków na terenie pozostałych przedsiębiorstw kolejowych;

- miernik wypadków, czyli liczba wypadków przypadająca na $1 \mathrm{mln}$ poc-km, wzrósł z 1,58 do 1,64, czyli o 3,8\%,

- liczba wypadków manewrowych wzrosła z 73 do 87, czyli o 19\%, w tym w Spółkach Grupy PKP - 84 wypadki, a 4 wypadki w pozostałych firmach.

\subsection{Ogólna charakterystyka wypadków}

Podstawowe przyczyny wypadków kolejowych są następujące:

wypadki pracownicze - zanotowano zmniejszenie wypadków $\mathrm{z}$ winy pracowników kolejowych z 20 do 13, co należy ocenić pozytywnie, gdyż wskazuje to na poprawę szkolenia oraz dobrą pracę bezpośredniego nadzoru, 
wypadki techniczne - nastąpił bardzo poważny wzrost takich wypadków z 46 do 83;

Do takich wypadków zaliczamy:

- wady techniczne nawierzchni - wzrost z 28 do 38 wypadków,

- wady techniczne wagonów - wzrost z 13 do 19 ,

- wady techniczne lokomotyw - wzrost z 5 do 26.

wypadki na przejazdach - nastąpił wzrost wypadków z 253 do 279 , tj. o $10,3 \%$ i te wypadki stanowią $70 \%$ ogółu wypadków z pociągami. Mimo wzrostu takich wypadków zmniejszyla się liczba ofiar, i tak:

- liczba zabitych zmniejszyła się z 42 do 32,

- liczba rannych zmniejszyła się ze 115 do 91.

\subsection{Stan techniczny infrastruktury kolejowej i pojazdów kolejowych}

Stan techniczny nawierzchni kolejowej ulega postępującej dekapitalizacji z uwagi na niedostateczną ilość wykonywanych robót utrzymaniowo naprawczych. Powoduje to wzrost zagrożenia bezpieczeństwa ruchu kolejowego.

Roczne potrzeby napraw głównych wynikające $\mathrm{z}$ cykli naprawczych wynoszą ok. $1390 \mathrm{~km}$, w 2006 roku wykonano $380 \mathrm{~km}, \mathrm{tj} .27 \%$, a potrzeby roczne wymian rozjazdów wynoszą ok. 2490 szt. rozjazdów, w roku 2006 wymieniono 242 rozjazdy, tj. 9,7\%. Należy podkreślić, że według potrzeb na koniec 2006 roku zaległości $w$ wykonaniu wymaganych napraw głównych wynoszą: $10300 \mathrm{~km}$ torów oraz 17100 szt. rozjazdów.

Obrazem dekapitalizacji infrastruktury kolejowej jest liczba wprowadzonych ograniczeń prędkości. Na koniec 2006 roku obowiązywało 4855 ograniczeń, a na koniec 2005 r. - 4239, co oznacza wzrost 0616 szt., tj. o $14,5 \%$.

Poprawa stanu podstawowej infrastruktury (torów i rozjazdów) wymaga następujących dzialań:

- radykalnego zwiększenia zakresów napraw głównych i napraw bieżących torów oraz rozjazdów,

- przyspieszenia tempa wymiany szyn obrobionych cieplnie,

- główny zarządca infrastruktury kolejowej PKP PLK S.A. powinna opracować i przedstawić Kierownictwu Resortu harmonogram likwidacji ograniczeń prędkości.

Ilość przestarzałych urządzeń sterowania ruchem kolejowym (mechanicznych i mechaniczno-elektrycznych) corocznie zmniejsza się, jednak wdrażanie nowoczesnych systemów sterowania jest zbyt powolne. 
W 2006 r. zanotowano dwukrotny wzrost wielkości opóźnień pociagów $\mathrm{z}$ powodu usterek $\mathrm{w}$ urządzeniach srk. Wynika to $\mathrm{z}$ wydłużenia czasu trwania usterek, a głównym powodem tego są poważne braki w zatrudnieniu wykwalifikowanych pracowników bezpośredniego utrzymania i wyeksploatowanie istniejących urządzeń.

Ponad dwukrotny wzrost ilości wykrytych usterek w taborze świadczy o złym stanie technicznym pojazdów kolejowych, co wskazuje na konieczność zdyscyplinowania pracy rewidentów taboru oraz podjęcia działań zmierzających do odnowienia parku taboru kolejowego.

Utrzymuje się duże zagrożenie bezpieczeństwa ruchu spowodowane kradzieżą i dewastacją elementów urządzeń srk, a wielkość opóźnień pociagów z tego tytułu w 2006 roku w porównaniu z rokiem poprzednim wzrosła o ponad $60 \%$. Wielkość opóźnień uzależniona jest od możliwości naprawy zdewastowanego lub skradzionego urządzenia, na co mają wpływ braki w zatrudnieniu personelu utrzymania. Ponoszone przez zarządców infrastruktury koszty kradzieży lub dewastacji urządzeń są nadal bardzo wysokie (ok. 8,2 mln zł w 2006 roku). Koszty te przekroczyły prawie czterokrotnie nakłady przeznaczone na remonty urządzeń srk.

W 2006 r. w stosunku do roku poprzedniego zanotowano wzrost liczby wypadków z 5 do 26 z powodu wad technicznych lokomotyw oraz wzrost wypadków - z 13 do 19 - z powodu usterek technicznych wagonów.

Niepokojący jest wzrost z 3 do 7 liczby wypadków związanych z niedostatecznym stanem taboru u przewoźników kolejowych poza Grupa PKP. Poważnym problemem jest znaczne wyeksploatowanie pojazdów trakcyjnych, o czym świadczy średni wiek eksploatacji, który w przypadku spółki PKP CARGO S.A. dla lokomotyw elektrycznych i spalinowych przekracza 29 lat, a wagonów towarowych przekroczył 24 lata.

Dodatkowym problemem jest zmniejszenie w roku 2006 liczby wykonywanych napraw i przeglądów okresowych.

W taborze pasażerskim średni wiek w eksploatacji wynosi:

- 28,9 lat w Spółce PKP Przewozy Regionalne,

- 21,5 lat w Spółce PKP Intercity.

Ponadto tabor ten posiada przestarzałe rozwiązania techniczne, w roku 2006 stwierdzono ponad 2-krotny wzrost ilości usterek wykrytych w eksploatowanym taborze na liniach kolejowych.

Poprawa bezpieczeństwa ruchu odnośnie pojazdów kolejowych wymaga następujących działań:

- obniżenia średniego wieku pojazdów kolejowych będących w eksploatacji poprzez wycofanie $\mathrm{z}$ eksploatacji najbardziej wyeksploatowanych pojazdów i zakupy pojazdów nowych, 
- przyśpieszenia modernizacji eksploatowanych pojazdów kolejowych, w szczególności lokomotyw ET22 i EP09,

- poprawę jakości wykonywanych przeglądów okresowych,

- zwiększenie nadzoru na jakością wykonywanych naprawę poprzez pilne powołanie niezależnego od przewoźników zespołu komisarzy odbiorczych.

Dla poprawy bezpieczeństwa ruchu związanego z wprowadzaniem do eksploatacji importowanych pojazdów kolejowych Prezes UTK powołał zespół do sprawy weryfikacji warunków dopuszczenia na polską sieć kolejową takich pojazdów (szczególnie dotyczy to warunków współpracy tor-pojazd).

\section{Diagnoza systemu bezpieczeństwa ruchu kolejowego w Polsce}

Dwoma jednostkami odpowiedzialnymi w Polsce za monitoring i ocenę bezpieczeństwa są Urząd Transportu Kolejowego (UTK), oraz Państwowa Komisja Badania Wypadków Kolejowych

Zadania Prezesa Urzędu Transportu Kolejowego w zakresie bezpieczeństwa ruchu $\mathrm{w}$ transporcie kolejowym wynikają z ustawy z dnia 28 marca 2003 roku o transporcie kolejowym i dotyczą w szczególności:

- nadzoru technicznego nad eksploatacją linii kolejowych i bezpieczeństwem ruchu kolejowego,

- nadzoru nad bezpieczeństwem przewozu koleją towarów niebezpiecznych.

Organizacja systemu zapewnienia bezpieczeństwa ruchu kolejowego przewiduje podział obowiązków i odpowiedzialność za jego stan na zarządców infrastruktury kolejowej, przewoźników kolejowych oraz użytkowników bocznic.

Zgodnie z art. 5 ustawy o transporcie kolejowym zarządca infrastruktury ma obowiązek utrzymywania infrastruktury kolejowej w stanie zapewniającym bezpieczne prowadzenie ruchu kolejowego.

Natomiast zgodnie z art. 17 tej ustawy, zarządcy, przewoźnicy kolejowi oraz użytkownicy bocznic zobowiązani są spełniać warunki techniczne i organizacyjne zapewniające:

- bezpieczne prowadzenie ruchu kolejowego,

- bezpieczną eksploatację pojazdów kolejowych.

Kolejną organizacją utworzoną w 2007 roku jest Państwowa Komisja Badania Wypadków Kolejowych. Działa ona przy ministrze właściwym do spraw transportu, prowadząc badania poważnych wypadków, wypadków i incydentów. Komisja wykonuje swoje zadania w imieniu ministra 
właściwego do spraw transportu. Komisja prowadzi postępowanie po każdym poważnym wypadku na sieci kolejowej, $\mathrm{z}$ wyłączeniem przypadków najechania pojazdu kolejowego na osoby podczas przechodzenia przez tory.

Komisja sporządza raport z postępowania zawierający zalecenia w zakresie poprawy bezpieczeństwa oraz zapobiegania poważnym wypadkom, wypadkom lub incydentom, przyjmując uchwałę w tym zakresie.

Zalecenia $w$ zakresie poprawy bezpieczeństwa oraz zapobiegania poważnym wypadkom, wypadkom lub incydentom nie mogą obejmować ustalania winy lub odpowiedzialności.

Komisja sporządza do dnia 30 marca roczny raport z prac Komisji w roku poprzednim, zawierający wydane zalecenia $w$ zakresie bezpieczeństwa i dzialania podjęte zgodnie $z$ tymi zaleceniami, oraz przesyła go do Agencji. Roczny raport ogłaszany jest nie później niż do dnia 30 września.

Komisja ogłasza raporty $w$ drodze obwieszczenia, $w$ dzienniku urzędowym ministra właściwego do spraw transportu.

Prezes UTK nadzoruje $\mathrm{w}$ ramach swoich kompetencji realizację zaleceń powypadkowych przekazywanych przez Komisję.

Prezes UTK przedstawia corocznie Komisji informację o realizacji zaleceń przekazanych przez Komisję oraz o podjętych działaniach zmierzających do realizacji tych zaleceń. akty wykonawcze z Dz.U. i M.P.

\section{Zasady programowania poprawy bezpieczeństwa}

Jak wynika z powyższych danych poważne wypadki kolejowe zdarzają się stosunkowo rzadko, mają one jednak katastrofalne skutki i wywołują zaniepokojenie opinii publicznej co do bezpieczeństwa kolei. Należy więc badać wszystkie zdarzenia pod kątem możliwości uniknięcia podobnych wypadków, a wyniki dochodzenia publikować. Incydenty i zdarzenia potencjalnie wypadkowe mogące spowodować wypadki powinny stanowić znaczące zdarzenia poprzedzające wypadki i również powinny być przedmiotem badania $\mathrm{w}$ zakresie bezpieczeństwa.

Raporty z dochodzenia oraz wszelkie wnioski i rekomendacje stanowią istotna informację $\mathrm{z}$ punktu widzenia dalszego rozwijania bezpieczeństwa kolei i powinny być one dostępne publicznie. Rekomendacje powinny być zrealizowane przez ich adresatów, a raporty $\mathrm{z}$ działań przekazane badającemu organowi dochodzeniowemu. Szczegółowe informacje na temat zawartości raportów $\mathrm{z}$ dochodzenia $\mathrm{w}$ sprawie wypadków i incydentów 
zawiera Załącznik V do Dyrektywy 2004/49/WE Parlamentu Europejskiego i Rady z dnia 29 kwietnia 2004r., w sprawie bezpieczeństwa kolei [2].

Europejska Rada Bezpieczeństwa w Transporcie (ETSC) w 2004 opublikowała raport zatytułowany "Wskaźniki bezpieczeństwa w transporcie", w którym postulowała rozwiązania mające na celu poprawę bezpieczeństwa we wszystkich rodzajach transportu, zarówno na poziomie europejskim, jak i krajowym. Należały do nich:

- stworzenie listy wskaźników bezpieczeństwa jako sposobu określania tendencji $\mathrm{w}$ poziomie bezpieczeństwa oraz oceny skuteczności programów ograniczania liczby ofiar wypadków;

- powołanie grupy roboczej, która opracuje listę istotnych wskaźników bezpieczeństwa;

- przeprowadzanie studiów wykonalności zbierania danych;

- wymaganie od krajów członkowskich, aby gromadziły dane o wskaźnikach bezpieczeństwa "w sposób jednolity i regularny" oraz aby bieżące monitorowanie bezpieczeństwa stało się "integralnym elementem ich strategii zapewnienia bezpieczeństwa narodowego";

- przekazanie krajom członkowskim wskazówek dotyczących metodologii monitorowania i gromadzenia danych;

- publikacja raportów wykazujących roczne tendencje w europejskich rocznikach statystycznych poprzez Internet, a także za pomocą Systemu Informacji o Bezpieczeństwie Drogowym Komisji Europejskiej;

- wymaganie od krajów członkowskich, aby regularnie dostarczały dane o wskaźnikach oraz wdrażały programy poprawy wskaźników

- wprowadzenie na listę zagadnień VI Ramowego Programu Badawczo-Rozwojowego dalszych badań nad sposobami przeprowadzania i oceniania zintegrowanych programów zarządzania bezpieczeństwem oraz ustalania zależności pomiędzy wskaźnikami a liczbą wypadków;

- wskazania najlepszych sposobów korzystania ze wskaźników bezpieczeństwa w transporcie [3].

$\mathrm{Na}$ tej podstawie dokonano podziału wskaźników bezpieczeństwa i przedstawiono je w następujący sposób:

\section{Wskaźniki bezpieczeństwa odnoszące się do wypadków:}

1. Całkowita i względna (w przeliczeniu na pociago-kilometry) liczba wypadków z rozbiciem na następujące rodzaje wypadków: 
- kolizje pociaggów, łącznie z kolizjami z obiektami wewnątrz skrajni;

- wykolejenia pociagów;

- wypadki na przejazdach kolejowych, łącznie z wypadkami z udziałem pieszych na przejazdach kolejowych;

- wypadki z udziałem osób, spowodowane przez poruszający się tabor kolejowy, z wyjątkiem samobójstw;

- samobójstwa;

- pożary taboru kolejowego;

- inne.

2. Całkowita i względna (w przeliczeniu na pociago-kilometry) liczba osób poważnie rannych i zabitych, wg rodzaju wypadku, podzielona na poniższe kategorie:

- pasażerowie (również w przeliczeniu na pasazero-kilometry);

- pracownicy, łącznie z pracownikami podwykonawców;

- użytkownicy przejazdów kolejowych;

- intruzi w pomieszczeniach kolei;

- inni.

\section{II . Wskaźniki bezpieczeństwa odnoszące się do incydentów i wypadków unikniętych:}

1. Całkowita i względna (w przeliczeniu na pociaggo-kilometry) liczba pękniętych szyn, klamer torów i defektów sygnalizacji.

2. Całkowita i względna (w przeliczeniu na pociago-kilometry) liczba przekazanych sygnałów awaryjnych.

3. Całkowita i względna (w przeliczeniu na pociago-kilometry) liczba pękniętych kół i osi w użytkowanym taborze kolejowym.

\section{Wskaźniki bezpieczeństwa odnoszące się do skutków wypadku:}

1. Całkowity i względny (w przeliczeniu na pociago-kilometry) koszt (w Euro) wszystkich wypadków, wraz, jeśli to możliwe, $\mathrm{z}$ obliczeniem $\mathrm{i}$ uwzględnieniem następujących elementów kosztów:

- dla przypadków ofiary śmiertelnych i obrażen;

- rekompensat za utratę lub zniszczenie własności pasażerów, personelu lub stron trzecich, uwzględniając szkody dla środowiska;

- zastapienia lub naprawy zniszczonego taboru i instalacji kolejowych; 
- opóźnień, zakłóceń i objazdów, w tym dodatkowych kosztów personelu i utraty przyszłych przychodów,

2. Całkowita i względna (w przeliczeniu na godziny przepracowane) liczba godzin pracy personelu i podwykonawców, utracona w wyniku wypadków.

\section{Wskaźniki odnoszące się do bezpieczeństwa technicznego infrastruktury i jego stosowania}

1. Procent torów działających z Automatyczną Ochroną Pociaggów (ATP) oraz procent pociaggo-kilometrów na torach wyposażonych w ATP.

2. Liczba przejazdów kolejowych (całkowita i na kilometr). Procent przejazdów kolejowych z barierami automatycznymi lub ręcznymi.

\section{Wskaźniki odnoszące się do zarządzania bezpieczeństwem}

Audyty wewnętrzne przeprowadzone przez zarządców infrastruktury i przedsiębiorstwa kolejowe zgodnie $\mathrm{z}$ dokumentacją systemu zarządzania bezpieczeństwem. Całkowita liczba wykonanych audytów i jako procent wymaganych (i/lub planowanych) audytów [5].

W myśl nowych przepisów odpowiedzialność za bezpieczeństwo ruchu kolejowego spoczywa na przewoźnikach kolejowych i udostępniających infrastrukturę kolejową. Prawidłowy system zarządzania bezpieczeństwem wymaga jednak podejścia systemowego.

Należy zaznaczyć że obecnie trwają intensywne prace komisji europejskich w zakresie problematyki stosowania wskaźników bezpieczeństwa.

\section{Podsumowanie}

Przy weryfikacji bezpiecznej pracy systemów w dziedzinach zagrożonych katastrofalnymi skutkami błędów, zasadniczy nacisk położony jest na identyfikację błędów, analizę ich przyczyn oraz na ograniczenie skutków. Przy określaniu bezpieczeństwa systemu powinny być zaangażowane obie strony: projektant - producent - dostawca, ale też przyszły użytkownik, który powinien mieć wpływ na określenie sytuacji niebezpiecznych, reakcji systemu na błędy i uszkodzenia (zwłaszcza w sytuacjach uznanych za niebezpieczne), a także określenie warunków implementacji i konserwacji systemu.

Rozwijana obecnie teoria bezpieczeństwa systemów, zwłaszcza we Francji, Wlk. Brytanii, St, Zjednoczonych i w Polsce, umożliwia skuteczne rozwiązanie sprzeczności między komplikacją struktury systemów 
transportowych, a potrzebą ich bezpiecznego i niezawodnego działania. Rozwiązanie tej sprzeczności będzie decydowało w następnych latach o bezpieczeństwie ruchu kolejowego. Intensywne włączenie się w rozwój teorii bezpieczeństwa systemów, umożliwi szybkie i bezpośrednie przeniesienia uzyskanych rozwiązań do praktyki eksploatacyjnej PKP.

Materiat przedstawiony $w$ artykule stanowi fragment projektu: Zintegrowany System Zarzadzania Bezpieczeństwem ZEUS - PBZ-MEiN$7 / 2 / 2006$

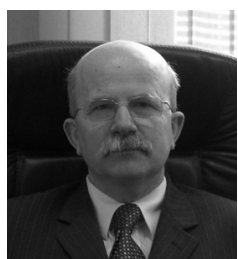

prof. Marek SITARZ, Professor of Silesian University of Technology, Head of Railway Engineering Department, Silesian University of Technology, Katowice, Poland, Chief editor of "Przegląd Komunikacyjny" (transport magazine). Author of some 120 publications, co-author of 4 monographs 